\title{
PUBLIC DIPLOMACY AND LANGUAGE TEACHING
}

\author{
Anna Antropovskaya \\ Teaching Assistant, Law Institute, RUDN University, RUSSIA, aniaantr@gmail.com
}

\begin{abstract}
Public diplomacy is extremely important in modern world. First, there are a lot of systems that could be used in order to speed up the dissemination of information. Second, there is a growing interest in other countries. Moreover, cultural exchange and fostering of contacts between people have always played an important role in international relations. Teaching of foreign languages helps to achieve the purposes of public diplomacy. This study aims at identifying different approaches to teaching foreign languages and acquaintance with culture of a country. These approaches were allocated and analyzed by examining the activities of cultural centers of France, Italy and India in Moscow. The methodology integrated theoretical studies and details of the work carried out by cultural centers of these countries. The research was based on the corporative analyses of French, Italian and Indian approaches to implementation of public diplomacy, namely teaching of foreign languages abroad, in particular, in Russia. Common features and differences of programs for learning foreign languages in the framework of public diplomacy were identified. The findings have revealed that France, Italy and India, despite the fact that their approaches are different, strive to create all the necessary conditions to make their language, culture and history attractive to Russian citizens. France focuses on language learning, Italy encourages contacts between Italians and Russians, and helps Russians learn more about job prospects in Italy. India is trying to make an emphasis on its culture. The results contribute to further developments of integration of formal and non-formal foreign language training tracks within the national curricula in different nations, as well as the integration of language training practice into the public diplomacy advance across countries.
\end{abstract}

Keywords: Public diplomacy, cultural centre, teaching of foreign languages.

\section{INTRODUCTION}

We are currently witnessing the evolution of public diplomacy. Firstly, this is due to the increase in the speed with which information is disseminated. Secondly, theincreasing interest to the culture of other countries is also noted (Zaharna, 2012).

The term "public diplomacy" appeared in 1965. That was when the dean of the Fletcher School of Law and Diplomacy at Tufts University Edmund Galion proposed this term to denote the impact on the population of other countries in order to form a positive image of the country (Cull, 2019). Subsequently, in 1990, an American political scientist, Harvard professor Joseph Nye proposed the term "soft power", noting that one of the most significant purposes of the soft power is the implementation of public diplomacy. He identified three main areas of public diplomacy: clarification of the domestic and foreign policy of the state, public debate on major political issues and the establishment of conditions for ensuring contact with a foreign audience 
through the creation of conferences, educational programs and cultural centres that help foreign citizens to know more about culture, history, traditions and language of the country (Nye, 2019).

Stdy of various means of implementation of public diplomacy by providing an opportunity to learn a foreign language is relevant, since nowadays there are many cultural centres in Moscow. The majority of these centres are attached to the embassies of their countries. In the era of globalization, the interaction of states is becoming increasingly intense. It is therefore important to get acquainted not only with the history, politics and culture of other countries, but also to understand the mechanisms by which states project their images abroad.

The theoretical background of the study integrates the research data of O.V. Lebedeva (Lebedeva, 2017), T.V. Zonova (Zonova, 2012) and other famous scientists who work in the field of public diplomacy.

The aim of the study is to analyze approaches to teaching foreign languages of cultural centres attached to the embassies of France, Italy and India in Moscow within the framework of the implementation of public diplomacy of these countries. In order to achieve this goal, the following targets were established: to consider the methods of teaching French, Italian and Hindi in cultural centres; analyze the approaches of France, Italy and India to teaching their language abroad in the context of the implementation of public diplomacy; identify the similarities and differences in the approaches of these three countries to language teaching in cultural centres.

The relevance of the research is connected with the need to analyze various methods of teaching foreign languages within the framework of the implementation of public diplomacy andthe importance of creating conditions for successful interaction between cultural centresattached to the embassies of France, Italy and India with Russians, especiallyregarding the limitation of social contacts due to COVID-19 pandemic in 2020.

\section{METHODOLOGY}

The research integrates theoretical and empirical analysis. Theoretical analysis includes the study of relevant academic literature on the research topic. The empirical research is based details of the work of French, Italian and Indian cultural centres attached to the embassies in Moscow. Research materials include academic publications on the research topic and textual information posted published on the websites of these centres. The choice ofthis topicis determined by the interest in the work of cultural centres, which provide socio-cultural and educational events in different languages.

For the purposes of analysis, the textual information was structured into cases, the substantive sections of which include information regarding the establishment and the activities of centres, their missions, various methods of teaching foreign languages in cultural centres, the approaches of countries to teaching their language in the context of the implementation of public diplomacy.

The empirical analysis was based on the method of comparative analysis, which involves describing and explaining the similarities and differences of the objects of study, namely, the cultural centres of France, Italy and India attached to the embassies in Moscow. First of all, the researches related to public diplomacy in general, as well as strategies for its implementation by these countries were considered. The approaches of France, Italy and India to the implementation of one of the aspects of public diplomacy, teaching the language abroad, in particular in Russia, were analyzed. In the study, textual information on the websites of these organizations was regarded as the actual data for a case-study for each organisation, such a technique has been used in a number of current studies (Atabekova, 2020).

\section{RESULTS}

In 2011, the French Ministry of Foreign Affairs established the French Institute for the implementation of public diplomacy. It was during that period that the term "cultural diplomacy" appeared in France, implying the expansion of the country's cultural influence abroad (Lane, 2017). It was assumed that branches of the French Institute would be opened in many countries with which France maintains diplomatic relations. The ambassador of France in a particular country should determine the program of events held by the Institute. The key element of activity of the French Institute was supposed to be the creation of conditions for acquaintance with the culture of France in general, as well as for learning of the French language. Currently, there are about 100 departments of the French Institute in various countries.

The French Institute was established in Russia in 2012. Its authority identifies three main areas of the organization's activities in Russia: the dissemination of knowledge about the culture of France, the creation of joint educational programs and learning the French language. Representative offices of the French Institute operate in Moscow and St. Petersburg. 
The French Institute provides a wide range of French courses. Certainly, division by the level of French language knowledge is supposed. Thematic courses are periodically being opened, which help students to learn French know more about particular areas. Most frequently, these courses are related to French culture. For example, it is possible to attend courses on French literature and cooking. Another important possibility is preparation for international exams. In addition to language courses, the French Institute regularly holds exhibitions, film screenings, thematic lectures and meetings with cultural figures.

Italy follows a similar approach. One of the most effective instruments of public diplomacy, according to the Italian Ministry of Foreign Affairs, is learning language.

Dante Alighieri's society, established in 1893 on orders of king, plays an important role in the spread of the Italian language abroad. Currently, this organisation is a member of European Union National Institutes of Culture and cooperates with the Italian Ministry of Foreign Affairs.

The Dante Alighieri Society focuses on an individual approach. It determines the wide range of programs for studying the Italian language. Students can choose a classical course,entailing comprehensive study of all aspects of the language, or an intensive one, based on a communicative approach. Groups are formed according to the level of language proficiency. It is also possible to study the language individually. The program could be created in accordance with the wishes of the student. For students with a high level of Italian there are courses of business Italian. Speaking, listening, reading and writing skills should be developed due to this programme. There are also courses for preparing for international exams. A distinctive feature of Dante Alighieri's society is the course program for corporate clients, focused on the opportunity to learn the Italian language for successful integration into the work environment.

But still, the cultural centre attached to the Italian embassies remains the main instrument of public diplomacy. The Italian Institute of Culture has been operating in Moscow since 1986. To implement the main task of public diplomacy, there are a lot of language courses and events that allow Russians to communicate with Italians living in Russia (Zonova, 2012).

The communicative method is a priority within the framework of learning language. The authority of the Institute highlights that the confidence in the ability to maintain a conversation and express their opinion is the main goal of learning a language. It motivates students to be interested in interaction with Italy. Moreover, the communicative method prevails in the programs of all seven levels. A possibility to prepare for international exam exists. There are alsospeaking clubs.

A slightly different approach is taken by Jawaharlal Nehru Cultural Centre attached to the Indian Embassy in Moscow. This centre was established since 1989. Its authority follows an integrated approach. It focuses on the culture and history of the country rather than on learning Hindi. The main purpose is strengthening bilateral relations in the cultural sphere, therefore, language learning is directly related to acquaintance with culture. In addition to courses, the Hindi cultural center provides an opportunity to practice national dances, yoga and playing the national tabla drum.

An individual approach in teaching Hindi is not provided. Students learn language in groups. The authority is focused on full immersion in culture, even at the initial stage of language learning. In addition to the basics of grammar, students immediately study the culture and traditions of the country. Teachers strive to interest students and involve them in studying not only Hindi, but Indian philosophy in general.

Education at Jawaharlal Nehru Cultural Center does not entail preparation for international exams, the curriculum itself is less regulated than in the cultural centers of France and Italy. But the Indian Cultural tries to motivate students. The best students get the opportunity to be awarded grants and have an opportunity to continue their study of Hindi and the country's culture.

\section{DISCUSSION}

Within the framework of this research, various approaches to the implementation of public diplomacy through language teaching in the cultural centres of France, Italy and India in Moscow were analysed. It should be noted that these countries are paying attention to the development of bilateral relations and the formation of an attractive image of their country in Russia.

Undoubtedly, in previous researches, including mentioned in this article, mechanisms for the implementation of public diplomacy have already been described. However, in this study, public diplomacy is examined from the perspective of approaches to teaching foreign languages and their comparative analysis. It determines the relevance of the proposed problematic. Notonly public diplomacy of France, Italy and India is considered, but also an analysis of specific ways of its implementation is carried out on the example of approaches to 
teaching methods language abroad.

The practical application of the results of this research is connected with the strengthening of public diplomacy. It is important to analyze the approaches of different countries to theactivity of cultural centres and analyze in detail the policy of embassies in Russia, aimed at shaping the image of their country. This article can help to understand the approaches of France, Italy and India to the implementation of public diplomacyin order to promote cooperation of the cultural centres of these countries both with Russiancitizens and with higher educational institutions. A cultural exchange will help to increase the interest of students and play a significant role in shaping a positive image of Russia abroad.

In addition, it should be noted that the experience of cultural centres can be used in order to improve the methods and practice of teaching foreign languages and the development of multilingual education in Russian universities. Nowadays, higher educational institutions of the Russian Federation consider foreign languages as a tool for ensuring professional superiority. Moreover, an experience of cultural centres of teaching foreign languages as a tool of public diplomacy can contribute to the development of solutions as responses to the challenges that higher education faces today (Atabekova, 2018) in terms of the insufficiently expressed orientation of educational technologies on the need to prepare specialists capable to combine their own professional activities and the presentation of the best scientific and applied professional practices in the multilingual multicultural space of the modern world community.

Moreover, the results contribute to further developments of integration of formal and non-formal foreign language training tracks within the national curricula in different nations, as well as the integration of language training practice into the public diplomacy advance across countries.

\section{CONCLUSION}

The article examines the approaches of France, Italy and India to teaching foreign languages in cultural centres attached to the embassies in Russia. The analysis results lead to the following conclusions.

Despite the differences in approaches, these countries strive to make their language, culture and history attractive to the citizens of Russia. France focuses on language teaching, Italy encourages contacts between Italians and Russians and helps Russians to know more about the prospects for working in Italy. Indiais trying to familiarize Russians with its culture. Language, according to the authority of Jawaharlal Nehru Cultural Centre, is a tool providing an opportunity to better understand the culture and mentality of the country.

It should be mentioned that cultural centres continue to operate despite the pandemic. Currently, all language courses are held remotely and cultural events are temporarily suspended. However, these cultural centres are actively using technical capabilities to keep the audience interested and attract an increasing number of Russians.

The results contribute to further developments of integration of formal and non-formal foreign language training tracks within the national curricula in different nations, as well as the integration of language training practice into the public diplomacy advance across countries.

There is a number of limitations of the article. Firstly, approaches of just three countries are considered. This limitation makes it impossible to identify other approaches to teaching foreign languages in cultural centres. Secondly, the main focus is precisely on relevant information. Further research involves the involvement of a larger number of countries, as well as consideration of the evolution of approaches of different countries to teaching a foreign language in Russia.

\section{REFERENCE LIST}

Atabekova, A (2020). University Discourse to Foster Youth's Sustainability in Society amidst COVID19: International and Russian Features. Sustainability, (18), 7336.

Atabekova, A. (2018, 5-7 March). Master Programs Taught in Foreign Languages: Students' Experience in research. 12-th International technology, Education, and development Conference (INTED). INTED Proceedings, 9569-9574.

Antyukhova, Ye. A., Bakhriyev, B. KH., Borishpolets, K. P., Dzhabbari, N. KH., Zinov'yeva, Ye. S., Zonova, T. V., ... \&Timofeyeva, O. A. (2017). Publichnaya diplomatiya: teoriya I praktika. Aspekt press. 
Zonova, T. V. (2012). Ital'yanskiyyazyk- soft power ili dolce potere? Dolce potere I publichnaya diplomatiyaltalii / T.V.Zonova // RIAC [Electronic resource]. - Mode of acceptance: https://russiancouncil.ru/analytics-and-comments/analytics/italyanskiy-yazyk-soft-power-ili-dolcepotere.

Lebedeva, O.V. (2017). Razvitiye publichnoy diplomatii kak prioritetnoye napravleniye deyatel'nosti diplomaticheskikh predstavitel'stv. Mezhdunarodnaya zhizn'. №2 (17).

Cull, N. J. (2019). Public diplomacy: Foundations for global engagement in the digital age. Polity Press.

Lane, P. (2017). La diplomatie culturelle, un atout pour la France. Campus France. № 27.

Nye, J. S. (2019). Soft power and public diplomacy revisited. Debating Public Diplomacy.

Zaharna, R.S. (2012). The Cultural Awakening in Public Diplomacy. Figueroa Press. 